\title{
A VIDÉKI TECHNIKATÖRTÉNETI VONZERŐK HASZNOSÍTÁSA A TERÜLETFEJLESZTÉSBEN
}

\section{THE UTILISATION OF THE LOCALTECHNICAL HISTORICAL ATTRACTIONS IN THE REGIONAL DEVELOPMENT}

\author{
Talpas János \\ Babeș-Bolyai Tudományegyetem, Földrajz Kar, Magyar Földrajzi Intézet; 400006 \\ Kolozsvár/Cluj-Napoca, str.Clinicilor nr. 5-7.Tel.: +40-745-656023; email: \\ talpasjanos@gmail.com
}

\begin{abstract}
The local technical historical attraction is a part of the regional development. The goal of the present paper consists in presenting the possible ways to integrate the local technical historical attraction to be a constituent of the touristic attraction. One of the possible ways to achieve this lies in the integration of technical historical attractions into the touristic itineraries, determining for this the palaces of the pictograms or symbols. To achieve practical application a case study was performed in Rimetea (Toróckó) town. Here were analyzed the expedience of different pictograms and symbols regarding their possible positioning.
\end{abstract}

Keywords: regional development, technical history, touristic symbols, pictograms, Torockó.

\section{Összefoglalás}

A vidéki technikatörténeti vonzóerő része a turisztikai területfejlesztésnek. A dolgozat célja megvizsgálni, hogyan lehetséges a technikatörténeti vonzóerőt integrálni a turisztikai vonzóeröbe. Ennek egyik módozata, mellyel a tanulmány foglalkozik, a technikatörténeti vonzóerők beillesztése a turisztikai útvonalakba, meghatározva a jelek/piktogramok helyszíneit. A gyakorlati hasznosítás végett egy esettanulmányt is végeztünk Toróckó településen. Elemeztük a különböző jelek és piktogramok hasznosíthatóságát, s ezek lehetséges elhelyezési helyszíneit.

Kulcsszavak: területfejlesztés, turisztikai jelek, turisztikai piktogramok, technikatörténet, Torockó.

\section{Bevezetés}

A technikatörténeti vonzerö meghoszszabbítja a turisták látogatási idejét, így lehetőség adódik a vendégéjszakák meghosszabbítására is. Ezek a vonzerők a vidéki turizmus esetében ritkán számítanak a települések turisztikai márkájának. A dolgozat elemzi a vonzerők beillesztésének lehetőségeit a helyi turizmusban és megha- tározza az ehhez szükséges jelek, illetve piktogramok elhelyezési helyszíneit.

Torockó turisztikai forgalma és a technikatörténeti vonzóerő léte határozta meg, hogy ezen a vidéken készítsünk egy esettanulmányt.

\section{A turisztikai jelek és piktogramok}

A turizmusban hasznos lehet, ha jelöljük a közlekedéssel kapcsolatos pontokat, att- 
rakciókat, illetve megközelítési irányokat, kiegészítő szolgáltatásokat és kapcsolódási irányokat [1].

Egy adott településre látogató turista fő tájékozódási pontjai általában a következők [2]:

- utak;

- határvonalak;

- körzetek;

- közlekedési csomópontok;

- könnyen észrevehetö tárgyak.

A technikatörténeti vonzóerők jelölése országos szinten még nincs kidolgozva. A romániai közlekedési kódex 12 turisztikai jelzőtáblát különböztet meg, ezek többnyire helymeghatározók [3] (1. ábra).

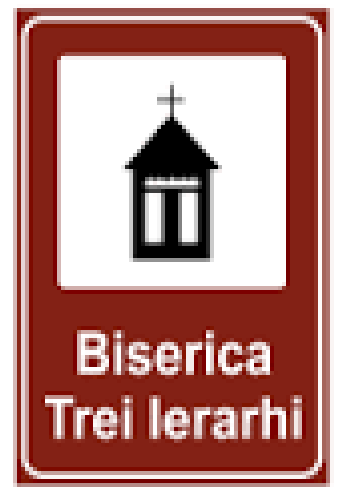

T4 - Bssericd

\section{1. ábra Turisztikai jelzötábla}

Magyarországon az Országos Müszaki Fejlesztési Bizottság végzett egy tanulmányt (OMFB 1992/93), amelyben a piktogramok általános funkcióit, jellemzőit és típusait elemzi. Az eredmény turisztikai vonásait Puckó László és Rátz Tamara dolgozta fel [1]. Ezek a következök:

- Információhordozók;

- Ergonómiát kielégítők;

- Megfelelnek a kor szellemének;

- Esztétikai élményt nyújtanak;

- Szociológiai aspektust hordoznak;

- Segítik a forgalmazást;

- Nyelvi korlátokat bontanak le.
A piktogramok felismerhetők, jól olvashatók, észlelhetők, könnyen megkülönböztethetők és könnyen memorizálhatók kell legyenek.

\section{Torockó - esettanulmány}

Torockó faluturizmusának vonzerői között szerepel a település központjában elhelyezett unitárius templom, az építészeti táj (lakóházak), irodalmi örökség, népviselet, festett bútorok, és nem utolsósorban a kirándulási lehetőségek a Székelykőre [4]. A fehér megyei bemutató szerint a turisztikai vonzóerő-felsorolás a következő: XVIII. századi unitárius templom, jellegzetes házak és népviselet, népi iparmüvészeti múzeum és Székelykő [5]. A terepet végigjárva, találkozunk útmutató turisztikai jelzésekkel és piktogramokkal. A turisztikai jelzések három útvonalat tüntetnek fel: a Székelykőre, az Ordaskőre, valamint a vasércbányákhoz vezető utat [6].

A vasércbányákhoz vezető túraútvonal felújitásra szorul. A település központi terén találunk útmutató táblákat, egyes vonzóerők esetében leírásos piktogramot is (2. ábra).

A központban elhelyezett táblán olvasható egy általános természeti-környezeti ismertetô. A piktogramok és a jelzőtáblák a helyi elképzelések szerint készültek és méretben, szerkesztésben, tematika szerint azonosak. A település bejáratainál viszont hiányoznak a turisztikai piktogramok. Helyenként technikatörténeti jelzések és táblák is fellelhetők (például vízimalom).

Torockó a középkorban jelentős vasalapanyagok (vascipó) és kovácsoltvas tárgyak termelési központja volt. Ennek köszönhetően ma a település bővelkedik technikatörténeti vonzerőkben. A vascipót a település határában kitermelt vasércböl állították elő. A vasércbányákhoz jelzés vezet. Az útvonal nincs igazán turisztikailag kidolgozva, hiányoznak a kilátópontok és egyéb turisztikai attrakciókkal kapcsolatos jelzések. Sok esetben a túraútvonal jelzése is hiányos. 


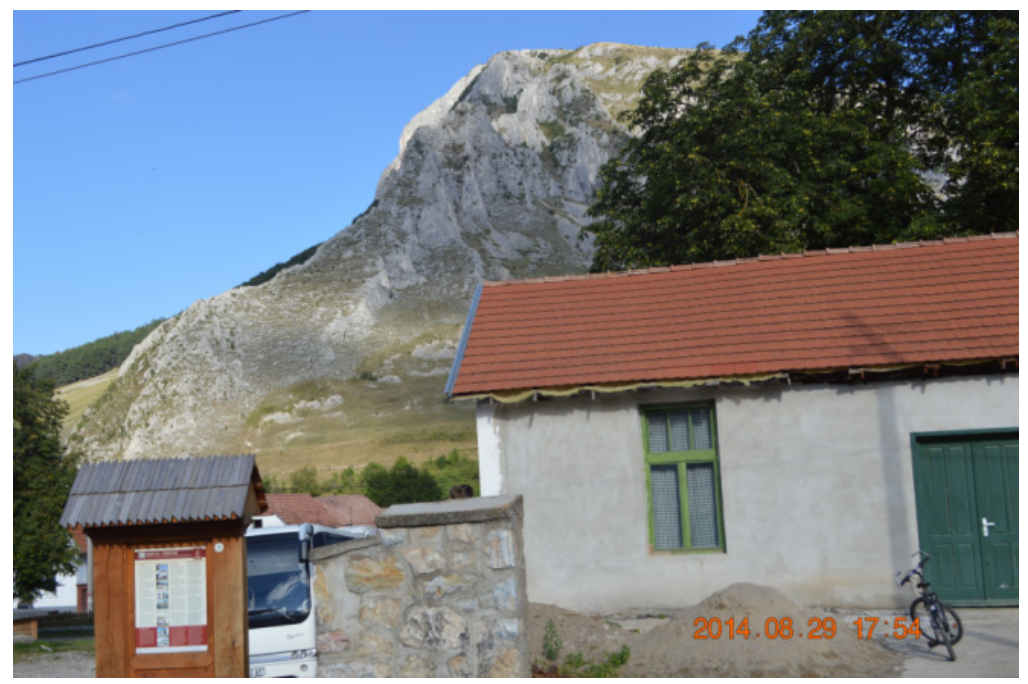

2. ábra Vonzóeröt jelölö tábla

A vasércolvasztás egyszerü módon történt, ennek emlékeit nem sikerült feltárni, pontosan meghatározni. A feltételezett vasércolvasztási technológiát meg lehet tekinteni a település múzeumában (rajz, makett).

A kovácsolási technológiák megmaradt részei a kalapácsokat meghajtó vízkerékszerkezet és vízvezető árok. Időközben ezek át lettek alakítva vízi malmokká. Napjainkban - a központhoz közel - egy ilyen típusú, látogatható szerkezetet találhatunk (3. ábra).

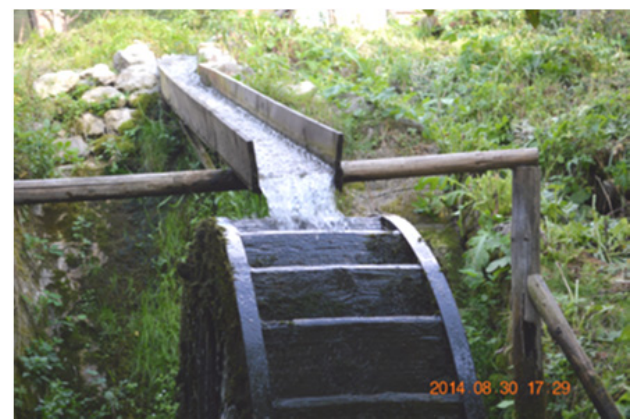

3. ábra Vizikerék hajtómü
A kovácsolás tárgyi értékei - zsaluk, kilincsek, szerszámok, rácsok- megtekinthetők a múzeumban, illetve a település különböző pontjain. A kovácsolt értékek látogatási útvonala nincs kialakítva.

Az unitáriustemplom vezető helyen szerepel a turisztikai vonzerők között, azonban a templom technikatörténeti vonzóeröi (toronyóra, harangok, kelyhek) nem tekinthetők meg, nem látogathatók a belső közlekedési nehézségek miatt (4. ábra). Ugyanakkor ezekről piktogramok sincsenek kihelyezve.

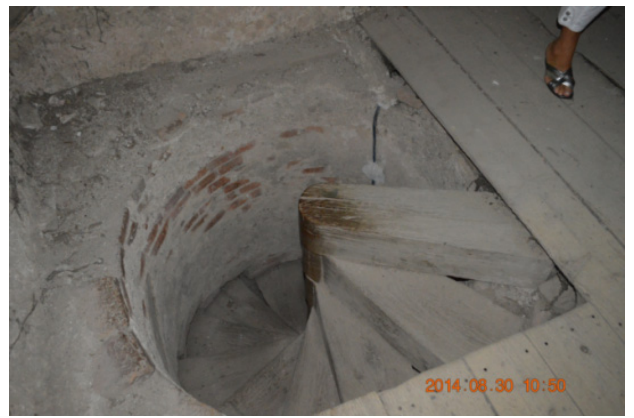

4. ábra Feljárat a toronyba 
A festett bútorok a múzeumban és házaknál láthatók. A házak esetében nincs megszervezve és kijelölve a bútorok megtekintése (5. ábra). Nincs lehetőség a szakmába való betekintésre.

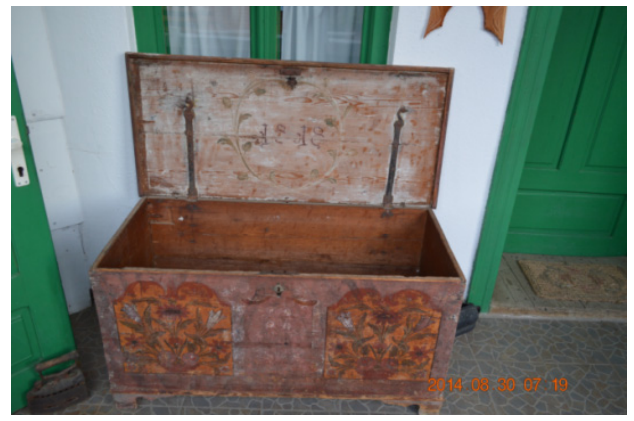

5. ábra Festett bútor a Panoráma panzióban

\section{Következtetések}

Torockó területén az utak és a közlekedési csomópontok nincsenek kellöképpen ellátva jelzőtáblákkal. Nem sikerült létrehozni egy rendezett parkolót, vagy akár kijelölni egy turisztikai érkező pontot, mely ne zavarja a látogató turistákat vagy a rendezvényeket. Ezt a helyszínt megfelelö piktogrammal szükséges jelölni. Ezeket a piktogramokat egyeztetni szükséges az országos közlekedési szervekkel. Az érkezési pont lehetne a turisztikai túraútvonalak kiinduló pontja. Itt láthatóvá tehetnénk a tejes túraútvonalat, melyben helyet kaphat- na technikatörténeti vonzerő is, így lehetöség nyílik ezek megismerésére. A templomban létező technikatörténeti vonzerők megtekintése érdekében javasolt egy látogatási program összeállítása. A kovácsolással kapcsolatos helyszínek megtekintése érdekében szükséges egy külön útvonal kialakítása,vagy összekapcsolása egy kulturális látogatási útvonallal. Minden esetben szükséges piktogrammal jelölni a helyszíneket. A festett bútorok esetében ugyanazok az intézkedések szükségesek, mint a kovácsolt tárgyak esetében. A piktogramok legyenek érthetők, esztétikusak, jól felismerhetők és ne tartalmazzanak szövegeket, így elkerülhetővé válnak a fordításokból származó félreértések.

\section{Szakirodalmi hivatkozás}

[1] Puczkó László, Rátz Tamara: Az attrakciótól az élményig, Budapest, 2011.p.180, 182.

[2] Goodey: Perception of the Enviromment, Birminghan, 1973, p.24.

[3] Noulcodrutier 2014 O.U.G. al Guvernului nr. $195 / 2002$.

[4] http:// wwwtorocko.eu, 2016. február 15.

[5] http.// www. székelyfoldiinfo.ro, 2016. február 15.

[6] Hantz-Lám Irén: Torockó Torockószentgyörgy, Studium kiadó, Kolozsvár, 2009, p. 193. 